Instructions for authors, subscriptions and further details:

\title{
http://rimcis.hipatiapress.com
}

\section{Towards an Insertion of Technologies: The Need to Train in Digital Teaching Competence}

Isabel María Gómez-Trigueros ${ }^{1}$, Santiago Ponsoda López de Atalaya $^{1}$, Rocío Díez $\operatorname{Ros}^{1}$

1) University of Alicante, Spain

Date of publication: Online First 30 November 2021; Issue published 30 November 2021

Edition period: November 2021 - March 2022

To cite this article: Gómez-Trigueros, I.M., Ponsoda, S., \& Díez, R. (2021).

Towards an Insertion of Technologies: The Need to Train in Digital Teaching Competence. International and Multidisciplinary Journal of Social Sciences, 10(3), 64-87. doi: 10.17583/rimcis.8652

To link this article: http://doi.org/10.17583/rimcis.8652

\section{PLEASE SCROLL DOWN FOR ARTICLE}

The terms and conditions of use are related to the Open Journal System and to Creative Commons Attribution License(CC-BY). 


\section{Towards an Insertion of Technologies: The Need to Train in Digital Teaching Competence}

Isabel María Gómez-Trigueros

University of Alicante
Rocío Díez Ros

University of Alicante

Santiago Ponsoda López de Atalaya

University of Alicante

\section{Abstract}

The purpose of this study is to analyze the perception of the digital teaching competences of the students of the Degree in Pre-School Education, Degree in Primary Education and Master in Teacher Training for Secondary Education. Additionally, this paper includes the students' perception of their teachers' digital competence. A mixed non-experimental methodology has been used with 428 the University of Alicante students participating. The results show a positive perception of the students about their digital teaching competence with contrasts with a deficient evaluation in relation to the digital teaching training of their teaching staff. Based on these results, the need to apply an improvement in the manipulative and didactic technological training of university teachers is corroborated as well as an adaptation of the teaching skills to the needs of the ICS in order to be able to carry out the correct preparation of the teaching staff in training.

Keywords: technology, teacher, ICT, competence, digital 
Sciences Vol. 10 No. 3 November 2021 pp. 64-87

\section{Hacia una Inserción de las Tecnologías: La Necesidad de Formarse en Competencia Digital Docente}

Isabel María Gómez-Trigueros

Universidad de Alicante
Rocío Díez Ros

Universidad de Alicante

Santiago Ponsoda López de Atalaya

Universidad de Alicante

\section{Resumen}

El objetivo de este estudio es analizar la percepción de las competencias docentes digitales de los estudiantes de los grados en Educación Infantil, Grado en Educación Primaria y Máster en Formación del Profesorado de Educación Secundaria. Además, este documento incluye la percepción de los estudiantes sobre la competencia digital de su profesorado. Se ha utilizado una metodología mixta no experimental con la participación de 428 estudiantes de la Universidad de Alicante. Los resultados muestran una percepción positiva de los estudiantes sobre su competencia docente digital contrastando con una evaluación deficiente en relación a la formación docente digital de su profesorado. A partir de estos resultados se corrobora la necesidad de aplicar una mejora en la formación tecnológica manipulativa y didáctica del profesorado universitario, así como una adecuación de las competencias docentes a las necesidades de la SIC para poder llevar a cabo la correcta preparación de los profesores. el profesorado en formación.

Palabras clave: tecnología, profesorado, TIC, competencia, digital 
oday's information and communication society (ICS) has given rise in Spain to a series of changes and transformations in the field of ( education, which have been complemented by the inclusion of Spanish universities in the European Higher Education Area (EHEA) ${ }^{1}$. Such developments have modified teaching and learning (T-L) methodologies and models, whose objective is to achieve a higher education system that is suitable for the new requirements of the ICS. In order for such changes to be implemented, universities have needed to incorporate technological tools that allow the university context to be adapted to the current reality by providing university institutes and departments with resources such as PCs and internet connection (Marín et al., 2012). However, the mere inclusion of information and communication technologies (ICTs) alone has not been sufficient to promote genuine and profound change (Roig-Vila et al., 2015). What is required in this respect is the involvement of all the actors that contribute to educational processes, with special attention paid to the role of teaching staff and their digital competence (Gutiérrez et al., 2010; Ortega \& Gómez, 2017). This is because, in this context, teachers play a central role in the appropriate incorporation of new technological resources in the classroom. ICTs have given rise to a new T-L model, in which the teacher ceases to be the protagonist of the process and instead directs students as they master new content (concepts, procedures, attitudes) (De Benito et al., 2013), thereby providing them with the competencies that will enable them to undertake 'lifelong learning' (UNESCO, 1996).

These circumstances have led to the development of a new educational paradigm (Ortega \& Gómez, 2017) that requires the inclusion of ICTs in educational models and, consequently, the development of future teachers' competencies and skills in the use of technologies as basic instruments in their training (Roig-Vila et al., 2015).

This is the origin of the concept of competency contained in the OECD's 2003 project entitled 'Definition and Selection of Competencies' (DeSeCo) (Rychen \& Hersh, 2003). Since then, a set of basic competencies has been incorporated into essential learning for the citizens of the ICS. DeSeCo indicates a number of conditions that must be met for a competency to be selected as key or essential. Among these is the requirement that a competency should 'contribute to obtaining results of high personal or social value, be applicable to a wide range of contexts [...] and enable people who acquire it 
to successfully satisfy complex demands' (Mateo, 2010, p.5). Linked to this specification are so-called teaching or professional competencies that, to some extent, meet the need to structure the various professional families with reference to the EHEA. Although there are many and varied lists of teaching competencies for teachers at the primary (Perrenoud, 2004), secondary (Tejada, 2009), and university (Zabalza, 2003) levels, it is teachers' digital competence (TDC) that has become highly relevant in twenty-first-century educational contexts.

There are various models of digital teaching competence such as: ICT (Information and Communication Technology) Competency Standards for Teachers (ECD- ICT) developed by UNESCO (2008); National Educational Technology Standards for Teachers (NETS-T) employed in the USA (ISTE, 2008); the project "DIGCOMP: A Framework for Developing and Understanding Digital Competence in Europe" (Ferrari, 2013) among others.

The European recommendation of 2006 defines digital competence as involving 'the confident and critical use of ICT for work, leisure and communication. It is underpinned by basic skills in ICT [...] to communicate and participate in collaborative networks via the Internet' (European Union, 2006, p.5). This definition identifies the basic skills involved in digital competence, with an emphasis on information and communication management in social settings. In this sense, there are different definitions of what is understood by CDD its conceptualization is an ongoing line of debate (Padilla-Hernández et al., 2018). Thus, it can be understood as the set of knowledge, skills, and attitudes required by educators to support digital learning (Hall et al., 2014) or, also, as the capacities and abilities to use ICT as a methodological resource with didactic capacity (Tourón et al., 2018).

But beyond these or other definitions (examples), the truth is that CDD is an evolving competence throughout the professional career (PadillaHernández et al., 2018), which requires continuous training by part of the teaching staff. Although, currently, it is considered that the domain of the CDD by the university teaching staff is deficient (Domingo-Coscolla et al., 2020). In this respect, TDC would be the set of knowledge, skills, and attitudes that are necessary today to be functional in a digital environment. Taking into account all of these requirements, and being aware of the need for training in TDC, Spain's Instituto Nacional de Tecnologías Educativas y de Formación del Profesorado (INTEF) (National Institute of Educational Technology and 
Teacher Training) has developed a Common Framework for Digital Competence of Teachers (2017), which identifies five areas for full TDC proficiency among teachers:

- The first area is information literacy: this relates to the location, retrieval, storage, organization, and analysis of digital content.

- The second area is communication and collaboration: this relates to the ability to share resources online and through other digital tools, interacting in social networks.

- The third area is digital content creation: this involves reproducing existing knowledge while taking into account intellectual property rights and usage licences.

- The fourth area is security, in relation to data protection and personal safety.

- The fifth area is problem solving: it centres on adapting digital resources to each moment and purpose, resolving manipulative conflicts, and proposing a creative use of digital resources.

All of these requirements represent a vital part of teacher training studies, since these students will be the teachers of tomorrow. Their main task, other than developing subject-specific learning, will be to promote the transformation of society by orienting it towards the incorporation of technologies as essential tools for the global citizenry of the ICS. It is therefore essential that universities promote positive attitudes towards ICTs, providing appropriate training in TDC to facilitate a solid command of technological resources for classroom practice (Cabero, 2014).

Undoubtedly, for these competence requirements to filter through to trainee teachers, it is essential for university teachers to possess high-quality TDC (Gómez, 2015). Although it is true that one can detect a certain reticence to include ICTs in higher education based on negative beliefs regarding the pedagogy-technology pairing (Tirado \& Aguaded, 2014), this cannot prevail over the demand for the improved training of teaching professionals.

Taking into account all of the above, in order to help improve the training of future teachers it appears necessary to analyse the perceptions held by a sample of trainee teachers regarding their TDC and to compare it with their assessments of the TDC of their university teachers. 


\section{Materials and Methods}

\section{Objectives}

The objective of this article is to deepen our understanding of TDC, specifically in relation to students on bachelor's degrees in pre-school and primary education, and the proper inclusion of technologies in their work as teachers. Faced with the need to address the correct CDD training of teachers in this research has carried out a study on the perception of students in training for the Pre-School Teacher Degree, Primary Teacher Degree, and Master's Degree of Secondary Teaching at the Faculty of Education of the University of Alicante, Spain. It is a preliminary step to the preparation of training programs, which take into account the importance of adequate training in CDD for professionals in their initial training. In this sense, the objectives of this research are:

a) Understand the perceptions that the students - future teachers-have of the use of technologies for educational purposes.

b) Analyse the importance that future teachers give to their training in the manipulative and educational use of technological resources.

c) Study the preferences and ICT tools used by the students for teaching and learning within the social sciences.

d) Assess the behaviour of the data and the results obtained on the basis of participants' gender and programme of study.

e) Identify the students' assessment of the TDC of their university teachers.

\section{Research Design}

We carried out our study based on a descriptive, non-experimental approach, with the intention of obtaining the perceptions of teachers in training. To conduct the investigation, we deployed a non-experimental, exploratory research design based on the use of a questionnaire as a data gathering instrument (Pardo, Ruiz \& San-Martín, 2015). The study was conducted during the 2017-2018 academic year at the University of Alicante's Faculty of Education, over four stages (Gómez, 2015): a theoretical review of TDC, the TPACK model, PLEs, and previously completed studies; the design and 
70 Gómez-Trigueros, Ponsoda \& Díez-An Insertion of Technologies

subsequent validation of the instrument based on collaboration with professors at other Spanish universities; the subsequent gathering of data through the questionnaire; the analysis of the data obtained and the formulation of proposals for improving teacher training.

It should be stressed that this study is based on a mixed quantitative and qualitative model (Tashakkori \& Teddlie, 2008), in which an online questionnaire was administered.

Table 1.

Descriptive values according to age range, programme of study, and gender.

\begin{tabular}{|c|c|c|c|c|c|c|}
\hline \multirow[b]{2}{*}{ Age range } & \multirow[b]{2}{*}{ Total } & \multicolumn{2}{|c|}{ Bachelor's degree } & \multirow{2}{*}{$\begin{array}{c}\text { Master's } \\
\text { degree in } \\
\text { secondary } \\
\text { education }\end{array}$} & \multicolumn{2}{|c|}{ Gender } \\
\hline & & $\begin{array}{l}\text { Pre-school } \\
\text { education }\end{array}$ & $\begin{array}{l}\text { Primary } \\
\text { education }\end{array}$ & & Female & Male \\
\hline 18 years & 31 & 20 & 11 & 0 & 29 & 2 \\
\hline 19 years & 31 & 31 & 0 & 0 & 30 & 1 \\
\hline 20 years & 76 & 35 & 41 & 0 & 67 & 9 \\
\hline 21 years & 87 & 29 & 57 & 1 & 73 & 14 \\
\hline 22 years & 57 & 27 & 28 & 2 & 47 & 10 \\
\hline $\begin{array}{l}23 \text { to } 29 \\
\text { years }\end{array}$ & 106 & 42 & 35 & 29 & 58 & 48 \\
\hline $\begin{array}{l}30 \text { to } 40 \\
\text { years }\end{array}$ & 29 & 14 & 9 & 6 & 25 & 4 \\
\hline $\begin{array}{l}\text { Over } 40 \\
\text { years }\end{array}$ & 11 & 4 & 4 & 3 & 7 & 4 \\
\hline TOTAL & 428 & 202 & 185 & 41 & 336 & 92 \\
\hline
\end{tabular}

\section{Sample}

The study sample was selected on a non-probabilistic, directed, and intentional basis (Argibay, 2006,2009). It consists of 428 participants, all trainee teachers enrolled in a bachelor's degree in pre-school or primary education or a master's degree in secondary education during the 2017-2018 academic year. The sample is considered significant with respect to the current population total (Scheaffer et al. 1986; Buendía et al. 1998), and it consists of 336 women (78.5\%) and 92 men (21.5\%). The age range is between 18 years 
and over 40 years (Table 1). Sample members are distributed according to year of study as follows: $25.5 \%$ first year; $19.6 \%$ second year; $36.4 \%$ third year; and $18.5 \%$ fourth year.

\section{Instrument}

We measured the studied variables using the mixed questionnaire proposed by Gómez-Trigueros and Ortega (2014) and Gómez (2015). The questionnaire was adapted to the objectives of the study and validated by experts from the universities of Alicante, Murcia, and Burgos. It should be noted that this instrument consists of 25 items that are arranged in three content blocks: the first relates to the sample's socio-demographic characteristics (items 1-4); the second to teaching competencies (items 5-10); and the third to the sample's TDC (items 11-15) and the TDC of the university teaching staff (items 1625). Seventeen of the items in the questionnaire use a 5-point Likert scale that ranges from 1 ('strongly disagree') to 5 ('strongly agree'). The remaining questions are qualitative and of the guided open type, with the aim of obtaining students' opinions about their interests and motivations concerning their studies, as well as the nature of the training received in ICT and TDC. To corroborate the internal consistency and reliability of the questionnaire, we used Cronbach's alpha. This produced a result of $\alpha=.752$, indicating that the instrument has an acceptable and appropriate internal consistency for the proposed study (Hernández et al., 2003; Bisquerra et al., 2004).

In terms of the procedure, the questionnaire was distributed by email via Google Forms during the second semester of the 2017-2018 academic year. The students received the questionnaire through their University of Alicante email addresses, and they were informed of the purpose of the study and notified that their responses were confidential.

Regarding the research design, it should be noted that to analyze the quantitative data, we calculated descriptive statistics (mean and standard deviation) using SPSS v. 23 for Windows. We were able to confirm that the sample distribution was normal and that the different analyses produced homogeneous variance. Similarly, we carried out a one-way ANOVA to compare the results according to gender, age, and programme of study. 
72 Gómez-Trigueros, Ponsoda \& Díez-An Insertion of Technologies

\section{Analysis and Results}

First, we present the results of the descriptive statistics (standard deviation = $\sigma$; mean $=\bar{x}$ ) of each of the quantitative items (Table 2). In general, the results shown in Table 2 indicate that the students' perceptions of their teaching competence are positive. This can be seen in items Q8 and Q10 ( $\overline{\mathrm{x}} \geq 4.10 ; \sigma \leq$ 0.783), which highlight the importance that the students attach to teaching competencies within their teacher training.

In a similar vein, the sample members consider themselves to have sufficient training in the use of basic technological tools (Q11: $\overline{\mathrm{x}}=4.35 ; \sigma=$ 0.703 and Q14: $\overline{\mathrm{x}}=4.24 ; \sigma=0.806)$. Regarding TDC, students consider themselves capable of implementing new technologies in the classroom (Q12: $\overline{\mathrm{x}}=4.08 ; \sigma=0.703$ and Q15: $\overline{\mathrm{x}}=4.09 ; \sigma=0.786)$ and can select subjectspecific content on the internet for educational use $(\mathrm{P} 13: \overline{\mathrm{x}}=4.26 ; \sigma=0.619)$. The participants therefore believe that their digital competence is sufficient so as to be able to appropriately implement such manipulative and educational knowledge in their future work as teachers.

The results pertaining to the digital competence of their university teachers reveal that the students have a negative perception of their teachers' manipulative competence to appropriately use ICTs (Q16: $\bar{x} \geq 3.27 ; \sigma=0.702$ and Q24: $\overline{\mathrm{x}} \geq 3.12 ; \sigma=0.701$ ) and to introduce, for educational purposes, technological resources in the trainee teachers' teaching and learning processes, as shown by the data for items Q18 ( $\overline{\mathrm{x}} \geq 3.21 ; \sigma=0.714), \mathrm{Q} 20(\overline{\mathrm{x}}$ $\geq 3.17 ; \sigma=0.721)$, and Q22 ( $\mathrm{x} \geq 3.22 ; \sigma=0.703)$, which indicate that the participants' most frequent response is 'neither agree nor disagree'.

Having conducted a descriptive analysis of the items, we carried out a comparison of means through a t-test for independent samples, as well as a univariate analysis of variance using a one-way ANOVA (Table 3). Our aim was to compare and assess whether there are any significant differences according to the sample members' gender and programme of study in relation to the three blocks analysed, as well as the teachers in such studies. 


\section{International and Multidisciplinary Journal of Social Sciences, 10(3) 73}

Table 2.

Descriptive results ( $\bar{x}=$ mean; $\sigma=$ standard deviation $)$.

\begin{tabular}{|c|c|c|}
\hline Instrument item analysed & $\overline{\mathbf{x}}$ & $\sigma$ \\
\hline Q8. My studies met my expectations regarding my training in teaching competencies. & 4.51 & 0.557 \\
\hline $\begin{array}{l}\text { Q10. I think that ongoing training in teaching competencies during my professional } \\
\text { career is important. }\end{array}$ & 4.74 & 0.484 \\
\hline $\begin{array}{l}\text { Q11. I am familiar with and am able to correctly use software such as word processors, } \\
\text { spreadsheets, images, and presentations. }\end{array}$ & 4.35 & 0.703 \\
\hline $\begin{array}{l}\text { Q12. I am familiar with and am able to appropriately manage and share educational } \\
\text { content through Web } 2.0 \text { applications (blogs, wikis, forums, MOOCs, Drive, Dropbox, } \\
\text { Prezi, SlideShare, Moodle, Flickr, YouTube, and Digg, among others). }\end{array}$ & 4.08 & 0.703 \\
\hline $\begin{array}{l}\text { Q13. I am able to search for and select information and content on the internet in order } \\
\text { to use it for educational purposes. }\end{array}$ & 4.26 & 0.619 \\
\hline $\begin{array}{l}\text { Q14. I am familiar with the basic software and hardware (such as the Office suite and } \\
\text { the Chrome browser) that will be needed in my future work as a teacher, and I am able } \\
\text { to produce educational content using such resources. }\end{array}$ & 4.24 & 0.806 \\
\hline $\begin{array}{l}\text { Q15. I have the training required to properly implement ICTs in order to teach content } \\
\text { in the classroom. }\end{array}$ & 4.09 & 0.786 \\
\hline Q16. My teachers in the Faculty of Education have sufficient training in TDC. & 3.27 & 0.702 \\
\hline $\begin{array}{l}\text { Q17. Regarding question Q16, indicate whether your teachers are mostly men, mostly } \\
\text { women, or a mixture of men and women. }\end{array}$ & 2.83 & 0.521 \\
\hline $\begin{array}{l}\text { Q18. My teachers in the Faculty of Education have the ability to use ICTs as a } \\
\text { pedagogical and educational resource. }\end{array}$ & 3.21 & 0.714 \\
\hline $\begin{array}{l}\text { Q19. Regarding question Q18, indicate whether your teachers are mostly men, mostly } \\
\text { women, or a mixture of men and women. }\end{array}$ & 2.90 & 0.405 \\
\hline $\begin{array}{l}\text { Q20. My teachers in the Faculty of Education appropriately integrate ICTs into the } \\
\text { curriculum and in educational practice. }\end{array}$ & 3.17 & 0.721 \\
\hline $\begin{array}{l}\text { Q21. Regarding question Q20, indicate whether your teachers are mostly men, mostly } \\
\text { women, or a mixture of men and women. }\end{array}$ & 2.92 & 0.360 \\
\hline $\begin{array}{l}\text { Q22. My teachers in the Faculty of Education have provided me with appropriate } \\
\text { models that combine content, technology, and educational methods for my future work } \\
\text { as a teacher. }\end{array}$ & 3.22 & 0.703 \\
\hline $\begin{array}{l}\text { Q23. Regarding question Q22, indicate whether your teachers are mostly men, mostly } \\
\text { women, or a mixture of men and women. }\end{array}$ & 2.82 & 0.535 \\
\hline $\begin{array}{l}\text { Q24. My teachers in the Faculty of Education have sufficient training in and knowledge } \\
\text { of current technological tools such as Web } 2.0 \text { ICT resources, MOOCs, use of virtual } \\
\text { simulators and augmented reality, portfolios, e-activity, QR codes, and Google Earth }{ }^{\mathrm{TM}} \text {, } \\
\text { among others. }\end{array}$ & 3.12 & 0.701 \\
\hline $\begin{array}{l}\text { Q25. Regarding question Q24, indicate whether your teachers are mostly men, mostly } \\
\text { women, or a mixture of men and women. }\end{array}$ & 2.88 & 0.439 \\
\hline
\end{tabular}


74 Gómez-Trigueros, Ponsoda \& Díez-An Insertion of Technologies

The results indicate that there are almost no significant differences between men and women in relation to the analysed values (Table 3 ). The only significant difference between women $(\overline{\mathrm{x}}=4.96)$ and men $(\overline{\mathrm{x}}=4.21)$ relates to the importance given to training in teaching competencies during their professional careers, data on which was collected through Q10. A t-test produced a result of $\mathrm{p}=0.009$.

Table 3.

T-test for independent samples and one-way ANOVA by gender.

\begin{tabular}{|c|c|c|c|c|c|c|}
\hline \multirow{2}{*}{ Item } & \multicolumn{2}{|c|}{ Gender } & \multicolumn{2}{|c|}{ T-test } & \multicolumn{2}{|c|}{ ANOVA } \\
\hline & $\mathbf{F}$ & $\mathbf{M}$ & $\mathbf{t}$ & $\mathbf{p}$ & $\mathbf{F}$ & $\mathbf{p}$ \\
\hline Q8. & 3.50 & 3.55 & -.478 & 0.615 & 0.228 & 0.633 \\
\hline Q10. & 4.96 & 4.21 & 1.984 & 0.009 & 3.936 & 0.048 \\
\hline Q11. & 4.30 & 4.53 & -2.864 & 0.220 & 8.202 & 0.004 \\
\hline Q12. & 4.05 & 4.20 & 1.991 & 0.045 & 3.963 & 0.041 \\
\hline Q13. & 4.21 & 4.43 & -3.140 & 0.149 & 9.859 & 0.002 \\
\hline Q14. & 4.16 & 4.51 & -3.750 & 0.254 & 14.060 & 0.000 \\
\hline Q15. & 4.03 & 4.29 & -2.876 & 0.201 & 8.269 & 0.004 \\
\hline Q16. & 3.27 & 3.21 & 0.560 & 0.571 & 0.314 & 0.576 \\
\hline Q17. & 2.83 & 2.85 & -0.333 & 0.488 & 0.111 & 0.739 \\
\hline Q18. & 3.20 & 3.23 & -0.340 & 0.364 & 0.116 & 0.734 \\
\hline Q19. & 2.90 & 2.91 & -0.299 & 0.551 & 0.089 & 0.765 \\
\hline Q20. & 3.38 & 3.34 & 0.433 & 0.342 & 0.188 & 0.665 \\
\hline Q21. & 2.92 & 2.91 & 0.226 & 0.606 & 0.051 & 0.821 \\
\hline Q22. & 3.21 & 3.20 & -0.822 & 0.899 & 0.675 & 0.412 \\
\hline Q23. & 2.81 & 2.83 & -0.215 & 0.758 & 0.046 & 0.830 \\
\hline Q24. & 3.09 & 3.21 & -1.650 & 0.174 & 2.723 & 0.100 \\
\hline Q25. & 2.89 & 2.87 & 0.336 & 0.490 & 0.113 & 0.737 \\
\hline
\end{tabular}

In addition, the confidence interval limits for the difference indicate that for the variables Q11, Q13, Q14, and Q15, in the case of men and women, the value ' 0 ' is not included within the confidence interval limits for the difference. This indicates that, in the case of such items, the hypothesis of equal means can be rejected, and this is confirmed in the results of the t-test 
performed for these questions $(\mathrm{Q} 11 \mathrm{t}=-2.864$; $\mathrm{Q} 13 \mathrm{t}=-3.140$; $\mathrm{Q} 14 \mathrm{t}=-3.750$; $\mathrm{Q} 15 \mathrm{t}=-2.876$ ).

With regard to the performance of the one-way ANOVA (Table 3) to compare perceptions by gender (Table 3), significant differences emerged between men and women $(p<0.05)$ for the items related to the importance of teaching competence and TDC in the training of future teachers $(\mathrm{Q} 10 \mathrm{p}=$ 0.048; Q11 p = 0.004; Q12 p = 0.041; Q13 $\mathrm{p}=0.002 ; \mathrm{Q} 14 \mathrm{p}=0.000 ; \mathrm{Q} 15 \mathrm{p}$ $=0.004)$. In general, among these variables significant differences can be observed between men and women, with higher mean values for men in all cases except item Q10, which is related to the importance of teaching competence in teacher training ( $\mathrm{F} \overline{\mathrm{x}}=4.96 ; \mathrm{M} \overline{\mathrm{x}}=4.21)$.

The analysis of the block of questions relating to the training of the students' university teachers in manipulative digital competence (Q16, Q24) and teaching and educational competence (Q18; Q20; Q22) does not reveal important differences in terms of gender. And nor do the mean results exhibit notable differences between men and women. It should be noted that in all cases the value selected by the sample is 3 or close to 3 , which equates to the 'neither agree nor disagree' option on the Likert scale.

In order to understand the relationship between the perceptions that students have of TDC and their assessment of the TDC of their university teachers, we deployed a Pearson's linear correlation analysis (Table 4).

In the results obtained, we observed a strong correlation between the sample's perception of their university teachers' TDC (Q16) and their perception of their teachers' appropriate inclusion and use of these technological tools in the classroom (Q18, Q20), with values of $r=0.792$ and $\mathrm{r}=0.754$ respectively. There is also a strong correlation between Q18 and both Q20 and Q22 ( $r=0.805$ and $r=0.722$ respectively); these questions focus on the university teachers' training in the appropriate inclusion of ICTs in the curriculum for the purposes of the students' future teaching careers. Similarly, there is a strong positive relationship between the university teachers' ability to appropriately implement technologies and content for educational purposes (Q22) and their knowledge of new ICTs in the educational environment (Q24) $(\mathrm{r}=0.727)$.

However, consideration of the importance of ongoing training in teaching competencies during the professional career stage (Q10) has a positive but weak correlation with: the university teaching staff's training in TDC (Q16; r 
$=0.064)$; their ability to use ICTs as a pedagogical and educational resource $(\mathrm{Q} 18 ; \mathrm{r}=0.007)$; their ability to appropriately integrate ICTs into the curriculum (Q20; $r=0.089)$; the development of teaching and learning models that combine content, educational methods, and ICTs $(\mathrm{Q} 22 ; \mathrm{r}=0.059)$; and their knowledge of new technology-based educational tools currently on the market $(\mathrm{Q} 24 \mathrm{r}=0.090)$.

Table 4.

Pearson's $r$ bivariate correlations.

\begin{tabular}{|c|c|c|c|c|c|c|c|c|c|c|c|c|}
\hline & Q8. & Q10. & Q11. & Q12. & Q13. & Q14. & Q 15. & Q 16. & Q 18. & Q 20. & Q 22. & Q 24. \\
\hline Q8. & 1 & & & & & & & & & & & \\
\hline Q10. & 0.049 & 1 & & & & & & & & & & \\
\hline Q11. & $0.097^{*}$ & 0.039 & 1 & & & & & & & & & \\
\hline Q12. & $0.118^{*}$ & 0.053 & $0.449^{* *}$ & 1 & & & & & & & & \\
\hline Q13. & $0.145^{* *}$ & $0.115^{* *}$ & $0.396^{* *}$ & $0.378^{* *}$ & 1 & & & & & & & \\
\hline Q14. & -0.006 & 0.085 & $0.495^{* *}$ & $0.452^{* *}$ & $0.409^{* *}$ & 1 & & & & & & \\
\hline Q 15. & $0.249^{*}$ & 0.053 & $0.467^{* *}$ & $0.475^{* *}$ & $0.426^{* *}$ & $0.541^{* *}$ & 1 & & & & & \\
\hline Q 16. & $0.403^{* *}$ & 0.064 & $0.122^{*}$ & $0.158^{* *}$ & $0.159^{* *}$ & $0.260^{* *}$ & $0.233^{* *}$ & 1 & & & & \\
\hline Q 18. & $0.407^{* *}$ & 0.007 & $0.259^{* *}$ & $0.128^{* *}$ & $0.104^{*}$ & $0.562^{*}$ & $0.192^{* *}$ & $0.792^{* *}$ & 1 & & & \\
\hline Q 20. & $0.397^{* *}$ & 0.089 & $0.102^{*}$ & $0.181^{* *}$ & $0.135^{* *}$ & $0.218^{*}$ & $0.185^{* *}$ & $0.754^{* *}$ & $0.805^{* *}$ & 1 & & \\
\hline Q 22. & $0.428^{* *}$ & 0.059 & $0.101^{*}$ & $0.238^{* *}$ & $0.187^{* *}$ & $0.569^{*}$ & $0.226^{* *}$ & $0.572^{* *}$ & $0.722^{* *}$ & $0.710^{* *}$ & 1 & \\
\hline Q 24. & $0.375^{* *}$ & 0.090 & 0.154 & $0.148^{* *}$ & $0.153^{* *}$ & $0.134^{* *}$ & $0.157^{* *}$ & $0.566^{* *}$ & $0.592^{* *}$ & $0.574^{* *}$ & $0.727^{* *}$ & 1 \\
\hline
\end{tabular}

Moreover, we analysed the sample members' perceptions of their own digital competence as a pedagogical and educational resource (Q14), as well as their assessment of this competence among their university teaching staff (Q18) and of the university teaching staff's ability to provide appropriate training in this competence $(\mathrm{Q} 22)$. We found a strong positive correlation between Q14 and Q18 $(r=0.562)$ and between Q14 and Q22 $(r=0.569)$.

Finally, it should be noted that there is a negative correlation $(\mathrm{r}=-0.006)$ between students' expectations regarding their training in competencies during their bachelor's and master's studies (Q8) and the perceptions they have of their TDC (Q14). 


\section{Discussion and Conclusions}

Within today's socio-cultural and educational context of the information and communication society (ICS), technologies have progressively been incorporated into the training of future teachers. These technologies are presented as the basic tools for enabling citizens to have access to the knowledge and resources that are available on the internet and that allow them, through lifelong learning (UNESCO, 1972,1996), to continue to learn throughout their lives. In this sense, it is essential for new generations of teachers to acquire, within their training, an appropriate level of digital competence (Díez, 2012), defined not as mere activities relating to instrumental training but as the provision of skills to enable future teachers to access ICS content and to critically discern its educational use (Cabero \& Llorente, 2008; Ortega \& Gómez, 2017). It is thus necessary to provide appropriate training that is consistent with society's demands (Buchberger et al., 2000); this reflects the need to adopt measures that are aimed at training teachers and that are adapted to the new demands of the ICS (Mir, 2008). These changes will only be possible if current university teachers have sufficient TDC to enable students to be appropriately trained, particularly in the case of the programmes analysed in this study, namely bachelor's degrees in pre-school and primary education and master's degrees in secondary education. Competencies that must go beyond the technical use of ICT in reference to a set of sociocultural actions for the use of technology in teaching (Padilla-Hernández et al., 2018). Recognition of the use of technologies as one of today's teaching competencies appears in the EHEA guidelines, as well as in related research (Marín et al., 2012; Roig-Vila, 2015; Ortega \& Gómez, 2017). For this reason, it is essential to ascertain the knowledge acquired by trainee teachers and their perceptions of their training in TDC during their studies, with the aim of improving curricula and detecting deficiencies in their training in order to ensure appropriate professional development.

In view of the results obtained, and aware as we are of the difficulty of analysing the perceptions of a population such as this, we can state that trainee teachers have a positive evaluation of their teaching competencies and their TDC. These findings are in line with those found in studies such as that of Emine et al. (2014), who corroborate the interaction between digital training and positive receptions of such tools for teaching, or the analysis of Roig-Vila 
et al. (2015), who note trainee teachers' lack of difficulties in the manipulative use of technologies.

We note that participants attributed great importance to the TDC aspect of their training in relation to their future teaching work. This finding is consistent with other studies on this subject (Cabero, 2004; Prendes et al., 2010; Cabezas et al., 2014) that demonstrate that trainee teachers believe that they must have digital competence so that they can appropriately incorporate technological tools in their work. In this respect, the results we obtained differ by gender; women attributed greater importance to digital training than did men. These values should be considered in light of the different perceptions that men and women have of their ability in relation to the manipulative use of ICTs (Erdogan \& Sahin, 2010; Roig-Vila et al., 2015).

In the same way, the result of the effect size from the T-Test is between 0.6131 and 0.5891, considered as medium (between 0.5 and 0.8) (Padilla, 2018). In this sense, these results are made explicit in the conclusions in response to the indications of the reviewers. As conclusions we must say that the effect size of the results obtained is medium. In this work, we have decided to carry out an effect size analysis based on differences between groups, through Cohen's d tests. Also, the results of the T-Test have been taken into account. In both cases, a mean value effect size $(\geq 0.5)$ is found (Boulton, 2015; Padilla, 2018), indicative of the magnitude of the result found, which allows us to offer an estimate of the scope of our research. These results lead us to continue investigating this topic as we consider it interesting in future research to delve deeper to evaluate the implications that arise from the various conceptions-perceptions, by gender, in terms of teaching digital competence and, in this way, assess whether there are significant variations not only in terms of handling but also in reference to the adequate inclusion of ICT tools in classrooms.

Our analysis of the correlations between the variables confirms, in line with Gutiérrez et al. (2010), that there is a tendency to overlook the great educational potential of ICTs, because negative values arise at the nexus of the individual's training in teaching competencies and his or her digital competence to incorporate ICTs in the classroom. This is due to the fact that students tend to interpret the manipulative use of ICTs and their teacher training as two distinct areas, thus decoupling teaching competencies from the digital competence of the teaching staff. 


\section{International and Multidisciplinary Journal of Social Sciences, 10(3) 79}

Furthermore, the TDC of the teaching staff of the bachelor's and master's courses was not assessed favourably, both in terms of manipulative abilities and the capacity to appropriately incorporate technological resources in teacher training. These results are consistent with those from the study by Muñoz et al. (2011), who state that members of university teaching staff have an elementary knowledge of the basic tools (word processors, spreadsheets, and databases) but that this does not necessarily mean that they use them appropriately in the classroom for educational purposes. Although our analysis indicates that students consider ICTs to be very important in their training as teachers, their evaluations of their university teaching staff demonstrate that technologies are scarcely incorporated into the curricula of the programmes analysed. These findings corroborate the contributions of Rue and De Corral (2007), who show that ICTs have occupied, and still occupy, an important place in higher education curricula but, as Gómez-Trigueros and Ortega (2014) note, their full incorporation is a lengthy process that remains incomplete. When the CDD by gender of active teachers is observed, differences between women and men are detected in relation to the importance that students perceive about digital teaching competence, with male students giving more importance to this variable.

Examining the correlations between the variables confirms, in line with Marín et al. (2012), that ICTs have great educational potential, and also that there are ways to integrate these tools into curricula, since significant results were found at the nexus of the university teaching staff's ability to include technologies in the classroom and the presentation of appropriate learning models in which technologies have been included for educational purposes, and in turn there were strong correlations between the university teaching staff's technological abilities and students' receiving better training in digital competence.

All of this allows us to conclude that although the trainee teachers perceive their training in digital competence to be adequate, they do not rate the training of their teachers at the Faculty of Education in this competence very highly. The results of the research have important implications for teacher training. Firstly, they value the need to review the profile of future teachers who have to train citizens, in order to establish what priorities, in the form of digital competences, they need to provide to the population so they can actively participate in today's society. Secondly, to show that the profile of higher 
education professionals needs to be adjusted to the needs of 21 st century society (European Union, 2006; OECD, 2010) in relation to their CDD. The causes of this imbalance between the demand for digital skills of active teachers and the needs of teachers in training is found, among others, in the scant importance given so far to complete teacher training. In spite of the great efforts made by educational authorities to make progress in terms of technological enhancement, training, and curricular inclusion, there is still a long way to go for university teachers to have sufficient grasp of technologies in order to meet the demands of the ICS. Therefore, we consider appropriate the development of concrete action proposals that allow the explicit incorporation of CDD in the study plans for the initial training of prospective teachers (Domingo-Coscollola, 2020).

By the same token, our study reveals an intimate relationship between university teachers' level of digital competence and the appropriate digital training of trainee teachers. Therefore, as Cabero (2004) indicates, change in education can come about by first of all transforming the mentality of university teaching staff regarding ICTs and, as Mishra and Koehler (2006) indicate, by appropriately including technology in the educational context.

The results of this article have, undoubtedly, an effect on the improvement of society since: it provides a teaching key for teachers in faculties of education in relation to the importance of including, in an appropriate manner, technologies in the classroom with models such as TPACK; it informs on the perception of students, future teachers, and their training in digital competence and the importance of continuing to deepen it; offers quantitative and qualitative data to educational administrations to continue investing in the training of teachers in digital competencies; presents the reality of inequalities in the use of technologies between women and men and helps us to understand, as members of society, the importance of change in education by transforming the approach to ICT in ICS. In this line, and to conclude, we insist that thanks to this type of studies (qualitative and quantitative) on the perception of women and men on technologies for teaching and learning, new ways of intervening in the classroom with technologies are being proposed, from a non-sexist perspective (Gómez-Trigueros et al., 2021), enriching the teaching task in the society of the 21 st century. 


\section{International and Multidisciplinary Journal of Social Sciences, 10(3) 81}

Regarding the limitations of this study, it should be noted that our research is currently ongoing, since we are yet to analyse other dimensions, such as the relationship between the considerations analysed and students' age and gender.

Likewise, it should be pointed out that this study's geographical scope was limited to the University of Alicante, and so the findings may not be generalizable to the entire teaching community across Spain. In addition, we used non-probabilistic convenience sampling, which has limitations when it comes to drawing general conclusions. Ideally, the instrument could be extended to all Spanish universities in order to corroborate or refute the assessments presented here. It would also be interesting to go into more depth regarding how these perceptions manifest themselves in, for example, trainee teachers' placements in schools, in order to confirm or otherwise some of the assertions that we observed.

In light of the above considerations, and as the ultimate objective of this study, our concern is to show the relationship between university teachers' technological competence and trainee teachers' acquisition of TDC. Thus, what we believe is needed is an improvement in university teachers' digital competence, along with a change in the way in which technologies are incorporated in the classroom. This requires a suitable relationship between the manipulative use of ICTs, the development of curriculum content, and the educational value of technological resources. Only through these measures will the teachers of tomorrow have the proper TDC required for their professional work in order to help individuals become full citizens of the ICS.

\section{Notes}

${ }^{1}$ This work is the result of the ongoing investigation of the Emerging Project GV/2021/077 "La brecha digital de género y el modelo TPACK en la formación del profesorado: análisis de la capacitación digital docente" led by Isabel María Gómez-Trigueros.

\section{References}

Argibay, J.C. (2006). Técnicas psicométricas. Cuestiones de validez y confiabilidad. Subjetividad y Procesos Cognitivos, 8, 15-33. https://www.redalyc.org/pdf/3396/339630247002.pdf 
82 Gómez-Trigueros, Ponsoda \& Díez-An Insertion of Technologies

Argibay, J.C. (2009). Muestra en investigación cuantitativa. Subjetividady Procesos Cognitivos, 13(1), 13-29.

http://www.scielo.org.ar/pdf/spc/v13n1/v13n1a01.pdf

Bisquerra, R. (coord.) (2004). Metodología de la investigación educativa. La Muralla.

Boulton, A. (2015). From research to research synthesis in CALL. In F. Helm, L. Bradley, M. Guarda, \& S. Thouësny (Eds), Critical CALL Proceedings of the 2015 EUROCALL Conference, Padova, Italy, 8490.Research-publishing.net. https://doi.org/10.14705/rpnet.2015.000314

Buchberger F, Campos, B.P, Kallos, D., \& Stephenson, J. (2000). Green paper on teacher Education in Europe. Thematic Network on teacher education in Europe.

Buendía, L., Colás, M.P., \& Hernández, F. (1998). Métodos de investigación en Psicopedagogía. McGraw-Hill.

Cabero, J. (2004). Formación del profesorado en TIC. El gran caballo de batalla. Comunicación y Pedagogía: Revista de Nuevas Tecnologías y Recursos Didácticos, 195, 27-37.

http://www.centrocp.com/formacion-del-profesorado-en-tic-el-grancaballo-de-batalla/

Cabero, J., \& Llorente, M. C. (2008). La alfabetización digital de los alumnos. Competencias Digitales Para El Siglo XXI. Revista portuguesa de Pedagogía, 42(2), 7-28. http://doi.org/10.14195/16478614 42-2_1

Cabero, J., \& Marín, V. (2014). Miradas sobre la formación del profesorado. Enlace. Revista venezolana de Información, Tecnología y Conocimiento, 11(2), 11-20.

https://produccioncientificaluz.org/index.php/enlace/article/view/1886 6

Cabezas, M., Casillas, S., \& Pinto, A.M. (2014). Percepción de los alumnos de Educación Primaria de la Universidad de Salamanca sobre su competencia digital. EDUTEC, Revista Electrónica de Tecnología Educativa, 48. https://doi.org/10.21556/edutec.2014.48.156

De Benito, B., Darder, A., et al. (2013). Agregación, filtrado y curación para la actualización docente. Pixel-Bite, 42, 157-169. https://recyt.fecyt.es/index.php/pixel/article/view/61576/37589 
International and Multidisciplinary Journal of Social Sciences, 10(3) 83

Díez Gutiérrez, E.J. (2012). Modelos socioconstructivistas y colaborativos en el uso de las TIC en la formación inicial del profesorado. Revista de educación, 358, 175-196. https://doi.org/10.4438/1988-592X-RE2011-358-074

Domingo-Coscolla, M., Bosco, A., Carrasco Segovia, S.,\& Sánchez Valero, J.A. (2020). Fomentando la competencia digital docente en la universidad: Percepción de estudiantes y docentes. Revista de Investigación Educativa,38(1), 167-782.

http://dx.doi.org/10.6018/rie.340551

Emine, K., Emre, N., \& Kamil, N. (2014). Creencias sobre alfabetización mediática en profesores y estudiantes de Educación Primaria. Comunicar, 21(42), 119-127. http://dx.doi.org/10.3916/C42-2014-11

Erdogan, A., \& Sahin, I. (2010). Relationship between Math Teacher Candidates' Technological Pedagogical and Content Knowledge (TPACK) and Achievement Levels. Procedia-Social Behavioral Sciences, 2,2707-2711. http://dx.doi.org/10.1016/j.sbspro.2010.03.400 European Union (2006). Recommendation of the European Parliament and of the Council of 18 December 2006 on Key Competences for Lifelong Learning. 2006/962/EC. Official Journal of the European Union. 30.12.2006.

Ferrari, A. (2013). DIGCOMP: A framework for developing and understanding digital competence in Europe. IPTS. European Comission.http://digcomp.org.pl/wpcontent/uploads/2016/07/DIGCOMP-1.0-2013.pdf

Gómez, I. Ma (2015). Proyecto a partir del modelo TPACK para desarrollar el aprendizaje de la Geografía en los estudios de Grado de Educación Primaria (Tesis Doctoral). Universidad de Alicante.

Gómez-Trigueros, I. M., \& Ortega, D. (2014). Los MOOC en la Didáctica de la Geografía: Aplicaciones en la formación inicial del profesorado de Primaria. En R. Martínez \& E. Tonda (Eds.), Nuevas perspectivas conceptuales y metodológicas para la educación geográfica (pp. 229244). Universidad de Córdoba.

Gómez-Trigueros, I.M., Ortega-Sánchez, D., \& García Cobas, R. (2021). Brecha digital de género y coeducación: claves conceptuales y orientaciones metodológicas. Aula Magna. Proyecto clave McGraw Hill. 
84 Gómez-Trigueros, Ponsoda \& Diez-An Insertion of Technologies

Gutiérrez, A., Palacios, A. \& Torrego, L. (2010). Tribus digitales en las aulas universitarias. Comunicar, 34(17), 173-181.

https://doi.org/10.3916/C34-2010-03-17

Hall, R., Atkins, L., \& Fraser, J. (2014). Defining a Self-Evaluation Digital

Literacy for Secondary Educators: the DigiLit Leicester Project.

Research in Learning Technology, 22, 21440.

https://doi.org/10.3402/rlt.v22.21440

Hernández, R, Fernández, C., \& Baptista, P. (2003). Metodología de la Investigación. Editorial Mc. Graw Hill.

ISTE (2008). National Educational Technology Standards for Teachers.

International Society for Technology in

Education.https://www.iste.org/iste-standards

Marín, V., Vázquez, Llorente, M.C., \& Cabero, J. (2012). La alfabetización digital del docente universitario en el Espacio Europeo de Educación Superior. Edutec. Revista Electrónica de Tecnología Educativa, 39.https://doi.org/10.21556/edutec.2012.39

Mateo, L. (2010). Origen y desarrollo de las competencias básicas en

Educación Primaria. Temas para la educación. Revista Digital para profesionales de la enseñanza, 7.

https://www.feandalucia.ccoo.es/docu/p5sd6989.pdf

Mir, A. (2008). Las competencias transversales en la Universidad Pompeu

Fabra. La visión de los docentes y estudiantes de segundo ciclo.

RedU. Revista de Docencia Universitaria, 6(1).

https://doi.org/10.4995/redu.2008.6279

Mishra, P., \& Koehler, M. J. (2006). Technological Pedagogical Content

Knowledge: A new framework for teacher knowledge. Teachers

College Record, 108(6), 1017-1054.

https://www.tcrecord.org/content.asp?contentid=12516

Muñoz, P.C., González Sanmamed, M., \& Fuentes Abeledo, E.J. (2011).

Competencias tecnológicas del profesorado universitario: análisis de su formación en ofimática. Educación XXI, 14(2), 157-188.

https://doi.org/10.5944/educxx1.14.2.249

OECD (2010). Working Paper 21st Century Skills and Competences for New Millennium Learners in OECD Countries. EDU Working paper No. 41. Instituto de Tecnologías Educativas. 
International and Multidisciplinary Journal of Social Sciences, 10(3) 85

http://recursostic.educacion.es/blogs/europa/media/blogs/europa/infor mes/Habilida des_y_competencias_siglo21_OCDE.pdf

Official Journal of the European Union (2006). Recommendation of the European Union and of the Council of 18 December 2006 on key competences for lifelong learning (2006/962/EC).https://eurlex.europa.eu/LexUriServ/LexUriServ.do?uri=OJ:L:2006:394:0010:0 018:en:PDF

Ortega, D., \& Gómez-Trigueros, I.M. (2017). Las WebQuests y los MOOCs en la enseñanza de las Ciencias Sociales y la formación del profesorado de Educación Primaria. Revista Electrónica Interuniversitaria de Formación del Profesorado, 20(2), 205-220. http://dx.doi.org/10.6018/reifop.20.1.258551

Padilla, J.A. (23 de diciembre del 2018). t de student, U de Man Whitney, tamaño del efecto, potencia estadística, formato APA. [Archivo de video]. https://www.youtube.com/watch?v=opiBEae7G_Q

Padilla-Hernández, A., Gámiz-Sánchez, V.,\& Romero-López, M. (2019) Competencia digital docente: apuntes sobre su conceptualización. Virtualis, 10(19), 195-216.

https://www.revistavirtualis.mx/index.php/virtualis/article/view/286/3 23

Pardo, A., Ruiz, M.A., \& San-Martín, R. (2015). Análisis de datos en ciencias sociales y de la salud I. Síntesis.

Perrenoud, P. (2004). Diez nuevas competencias para enseñar. Graó Prendes, M.P., Castañeda, L., \& Gutiérrez, I. (2010). Competencias para el uso de TIC de los futuros maestros. Comunicar, 18 (35), 175-182. https://doi.org/10.3916/C35-2010-03-11

Rychen, D.S., \& Hersh, L. (2003). Definición y Selección de las Competencias (DeSeCo): Fundamentos teóricos y conceptuales de las competencias. OCDE.

Rodríguez-García, M., Martínez, N., \& Raso, F. (2017). La formación del profesorado en competencia digital: clave para la educación del siglo XXI. Revista Internacional de Didáctica y Organización Escolar, 3(2), 46-65. http://hdl.handle.net/10481/61748

Roig-Vila, R., Mengual-Andrés, S., Sterrantino, C., \& Quinto, P. (2015). Actitudes hacia los recursos tecnológicos en el aula de los futuros 
86 Gómez-Trigueros, Ponsoda \& Diez-An Insertion of Technologies

docentes. @tic.Revistad'innovació educativa, 15, 12-19. https://doi.org/10.7203/attic.15.7220

Rué, J., \& De Corral, I. (2007). Significados de la "Formación docente" en las universidades españolas en el marco del EEES. Red U. Revista de Docencia Universitaria, 5 (2). doi:

https://doi.org/10.4995/redu.2007.6273

Scheaffer R, Mendenhall W., \& Ott L. (1986). Elementos de muestreo. Grupo Editorial Iberoamericano.

Tashakkori, A., \& Teddlie, C. (2008). Quality of inferences in Mixed Methods Research: Calling for an integrative framework. In M. Bergman (Ed.), Advances in Mixed Methods Research: Theories and Applications (pp. 101-119). Sage Publication, Inc.

Tejada, J. (2009). Competencias docentes. Profesorado. Revista de curriculum y formación del profesorado, 13(2). https://www.ugr.es/ recfpro/rev132COL2.pdf

Tirado R., \& Aguaded, J.I. (2014). Influencias del profesorado sobre el uso de la tecnología en las aulas. Revista de Educación, 363, 230-255. http://doi.org/10.4438/1988-592X-RE-2012-363-179

Tourón, J., Martín, D., Navarro, E., Pradas, S., \& Íñigo, V. (2018). Validación de constructo de un instrumento para medir la competencia digital docente de los profesores (CDD). Revista Española de Pedagogía, 76(269), 25-54. https://doi.org/10.22550/REP76-1-201802

UNESCO (1972). Aprender a ser: la educación del futuro. UNESCO.

UNESCO (1996). La educación encierra un tesoro, informe a la UNESCO de la Comisión Internacional sobre la Educación para el Siglo XXI. UNESCO.

UNESCO (2008). Estándares de competencias en TIC para docentes. http://eduteka.icesi.edu.co/articulos/EstandaresDocentesUnesco

Zabalza, M. A. (2003). Competencias docentes del profesorado universitario. Calidad y desarrollo Profesional. Narcea. 
International and Multidisciplinary Journal of Social Sciences, 10(3) 87

Isabel María Gómez-Triguerois member of the Department of General and Specific Didactics, University of Alicante, Spain

Santiago Ponsoda Lóez de Atalaya is member of the University of Alicante, Spain

Rocío Díez Ros is member of the University of Alicante Email: isabel.gomez@ua.es 